\title{
Undergraduate Research as an Institutional Ethos-A Case Study Examining a Faculty-Sponsored Research Symposium
}

\author{
Daniel M. Settlage \\ University of Arkansas - Fort Smith \\ dan.settlage@uafs.edu \\ Latisha A. Settlage \\ University of Arkansas - Fort Smith \\ latisha.settlage@uafs.edu
}

The importance of undergraduate research as a means of engaging students in higher order levels of thinking has become increasingly recognized in literature. Engaging undergraduate students in research has been shown to increase student-success outcomes including greater levels of retention (Kuh, 2008). Further research has demonstrated that high-impact practices including undergraduate research result in higher rates of faculty and peer interaction, increased critical thinking and writing skills, and higher levels of engagement (Brownell \& Swaner, 2009). Additional studies (Kilgo, Sheets, \& Pascarella, 2015; Craney et al. 2011) suggest that these benefits span disciplinary areas, and more still (Nnadozie, Ishiyama, \& Chon, 2001; Lopatto, 2004; Russell, Hancock, \& McCullough, 2007) conclude that undergraduate research opportunities help clarify students' interest in graduate level research and define their career paths. The literature further suggests that benefits accrue most greatly to those in underrepresented groups including racial minorities and first-generation students (Gregerman et al. 1998; Ishiyama, 2007; Barlow and Villarejo 2010; Finley \& McNair, 2013).

Given these observations, it is somewhat surprising that undergraduate research is promoted at many institutions in a largely piecemeal approach, usually targeting relatively small groups of select students such as those who are part of an honors program or those who seek out independent study or special topics courses. This is particularly true of many smaller state and regional institutions that tend to lack the resources to fully support both graduate programs and other research programs, have high faculty teaching loads, and tend to enroll high levels of students from historically underserved socioeconomic and demographic profiles.

This article outlines one regional institution's approach to systematically promoting and embedding undergraduate research as a high-impact practice that is available to the entire student population. Following Tinto's model of student persistence, which emphasizes both academic performance and faculty-student relationships as necessary elements for student success (Tinto, 1987), the institution's Undergraduate Research Symposium (URS) is a formal process developed to encourage, display, reward, and celebrate undergraduate research accomplishments that arise from student-faculty research collaborations. The URS was first proposed in 2007 by the provost of the university to increase undergraduate student research engagement. Over the intervening years, it has expanded to include 115 research presentations in 2020, and it underwent a name change to the Student Research Symposium in 2017.

\section{Background}

In the inaugural year of its symposium, the campus was a mere five years removed from being a community college that had previously granted only associate degrees and technical certificates. At the inception of the URS, research expectations of students and faculty were minimal. Since that time, the role and scope of the institution has significantly expanded to include new baccalaureate and graduate 
programs, as well as a substantial change in research expectations on the part of faculty. During this time, the URS has evolved to help fulfill the mission and vision of the university. This institutional journey provides background and direction to those wishing to replicate the transformative impact of integrating undergraduate research by forming a high-impact, campus-wide undergraduate research symposium. The remainder of this article will describe the mechanics of implementing the URS and describe observed benefits of this high-impact practice.

\section{Mechanics of the Symposium}

A standing university committee manages the processes and procedures of the URS. The committee includes a diverse faculty representation of disciplines across the campus. It coordinates and reviews the submissions, selects the judges, and manages the logistics of the seminar itself. A standing call for submissions is posted on the campus website throughout the academic year and actively promoted in the months leading up to the submission deadline. Students may submit projects in one of three categories: oral presentation, poster presentation, or artistic expression. Artistic expression includes studio or performing art. Performances are recorded and presented as viewings, rather than given as live performances. Poster presenters, studio and performing artists must be present during the symposium to discuss their projects with judges and other attendees.

Individual students and groups (of five or fewer members) work closely throughout the year on research projects that are guided and supervised by a faculty sponsor. Faculty sponsors provide students with guidance regarding abstract and project preparation, as well as support when seeking institutional review board approval (when needed). The faculty sponsors serve not only as research mentors, but as the first step in the quality assurance process. Sponsoring faculty members are required to proofread the individual or team abstract, and all abstract submissions come directly from the sponsoring faculty member. Substandard abstracts risk non-acceptance by the URS committee. Projects are encouraged from all areas of study and from students of any class standing. They may arise as the result of a class project or an independent research collaboration.

All accepted submissions are grouped with projects that are from similar disciplines and are judged by a panel of faculty selected by the URS committee. To reward academic performance, presentations, posters, and artists are judged on the following criteria (as pertinent): quality of written abstract, effectiveness of introduction, overall presentation quality, level of difficulty, accuracy of results, neatness/organization of format, form, content, craftsmanship, synthesis, creativity, engagement with audience, preparation, conclusion, and ability to respond to questions. Several top projects receive cash scholarships supported by the Office of the Provost and are spotlighted on the institution's social media.

\section{Benefits of the Symposium}

For many students, the URS is an introduction to further academic research. Many continue to present the same or future research at state, regional, national, or international conferences. In addition, undergraduate participants have successfully used their experiences as a springboard to graduate programs. Participation in the URS not only provides students with an advantage at application time, it empowers them with the foundation of research skills needed to excel in graduate school. This is an especially important experience for students in the socioeconomic and demographic profiles that are typically underrepresented in graduate school.

For faculty, the URS has served to increase faculty involvement in collaborative research with students and stimulate an increase in peer-reviewed presentations and publications. Many fruitful research projects began as a faculty guided ideas that saw first light at the URS. These presentations 
served as the steppingstone to more fully developed research ideas that have ultimately evolved into peer-reviewed journal articles. This is an especially important consideration at institutions that typically lack graduate programs and other infrastructure to fully support research activities, yet still require research from their faculty members. Perhaps even more important than potential publication is the human side of the experience. Engagement in the URS has deeply affected both student and faculty participants.

One example of a student-faculty project involved a cluster analysis of the regional economy. The student research was published in a quarterly report distributed to the community via the university's economic outreach center and had a clear impact on the student's future direction:

"I'd asked my professor if there was a project I could do that would give me a good feel for the field of economics, an area I'm interested in studying in graduate school. The project was a challenge, but the opportunity to use current theory and methods to address practical issues was very exciting to me."

Another project resulted in the student-faculty duo receiving a small research grant to complete their research project. The importance of the student-faculty mentoring model was clear in this student's assessment of the project:

"I am very thankful to have been mentored through this process. This institution offers a unique college experience. The professors are willing to work with the students and engage in the students' lives. It has been an amazing experience that I will never forget.”

Faculty members have also found participating in the symposium as a sponsor and judge to be an enriching experience:

"Serving as a judge for the URS has been an extremely rewarding experience. The scope of projects and the level of professionalism has been outstanding. It has inspired me to broaden my research base by working on projects with current students. This has become one of the most engaging and fruitful research activities in my portfolio."

\section{Conclusions}

Using a regional, teaching-focused state university as a case study, this article documents the formation and growth of a campus-wide annual URS and examines several positive changes in the institution's culture toward research as a result. The symposium is an idea that is easily adaptable and extendable to fit a wide variety of institutions and colleges. It can be scaled up to fit a large intuition or scaled down to fit within a single college on a large campus. The benefits of embedding undergraduate research in the ethos of the institution at such a deep level are powerful and widespread. Creating and enhancing a vibrant culture of research fosters a symbiotic relationship. Students, faculty, and the institution all benefit from placing an increased value on the undergraduate research experience. 


\section{References}

Barlow, A. E., \& Villarejo, M. (2004). Making a difference for minorities: Evaluation of an educational enrichment program. Journal of Research in Science Teaching, 41(9), 861-881.

Brownell, J. E., \& Swaner, L. E. (2009). High-impact practices: Applying the learning outcomes literature to the development of successful campus programs. Peer Review, 11(2), 26.

Craney, C., McKay, T., Mazzeo, A., Morris, J., Prigodich, C., \& De Groot, R. (2011). Crossdiscipline perceptions of the undergraduate research experience. The Journal of Higher Education, 82(1), 92-113.

Finley, A., \& McNair, T. (2013). Assessing underserved students' engagement in high-impact practices. Association of American Colleges and Universities. 1818 R Street, NW, Washington, DC 20009.

Gregerman, S. R., Lerner, J. S., Von Hippel, W., Jonides, J., \& Nagda, B. A. (1998). Undergraduate student-faculty research partnerships affect student retention. The Review of Higher Education, 22(1), 55-72.

Ishiyama, J. (2007). Expectations and perceptions of undergraduate research mentoring: Comparing first generation, low income white/Caucasian and African American students. College Student Journal, 41(3), 540.

Kilgo, C. A., Sheets, J. K. E., \& Pascarella, E. T. (2015). The link between high-impact practices and student learning: Some longitudinal evidence. Higher Education, 69(4), 509-525.

Kuh, G. D. (2008). Excerpt from high-impact educational practices: What they are, who has access to them, and why they matter. Association of American Colleges and Universities, 14(3), 28-29.

Lopatto, D. (2004). Survey of undergraduate research experiences (SURE): First findings. Cell Biology Education, 3(4), 270-277.

Nnadozie, E., Ishiyama, J., \& Chon, J. (2001). Undergraduate research internships and graduate school success. Journal of College Student Development, 42(2), 145-156.

Russell, S. H., Hancock, M. P., \& McCullough, J. (2007). Benefits of undergraduate research experiences. Science, 316(5824), 548-549.

Tinto, V. (1987). Leaving college: Rethinking the causes and cures of student attrition. University of Chicago Press, 5801 S. Ellis Avenue, Chicago, IL 60637. 